\title{
5. 医用画像ネットワーク技術
}

\section{1. ま え がき}

1970 年代から医㞠の画像検査・診断の分野ではディ ジタル技術が取入れられ，急激な革新が起こってき たこれは X 線 CT から始まり, 超音波, 核医学機 器, $\mathrm{X}$ 線機器のディジタル化, そして磁気共鳴イメ ージング(MRI) と続いており, ディジタル化画像の 割合は 1980 年代にかけ，ますます増えてきている 現在, 代表的な医療機関でのディジタル化画像の割合 は約 $20 \%$ といわているこの傾向は, ディジタル 機器の導入増加と, それぞれの機器の性能向上による 1 患者当たり情報量の増加により，ますます加速され ていこう

この新しい診断機器の普及に従い, 医㞠機関のうち で, 画像の保管・伝送に新しい画像の管理システムが 求められるようになってきた これが 1980 年代に入 り話題になってきた PACS (Picture Archiving and Communication Systems）の概念につながっている 1982 年, 第 1 回 PACS 国際会議・ワークショップが 米国でスタートし, 日本でも 1984 年第 1 回 PACS シ ンポジウムが開催され，今日まで年会議として続いて いる

PACS が病院内，あるいはまとまった医療機関の 組織内で企画され, 導入計画が考えられているのに対 し, もっと広い地域や遠隔地間で画像通信するサービ ス形態に Teleradiography と呼ばれる技術応用があ る医療画像をテレビ信号伝送として離れた場所へ送 るサービスは, ディジタル画像診断機器普及以前から 行われていた よく知られた例として, ボストンのロ ーガン空港の例がある 空港の診察室とマサチューセ ッツ総合病院をテレビ画像伝送ラインで結び, 空港に

$\dagger$ 株式会社東芝 医用機器事業部 医用機器技術研究所 株式会社東芝 那須工場 特機装置部

"Medical Imaging Network Technology" by Yoshı Yamagishı (Medical Electronics Laboratory, Medical Systems Division, To shiba Tochigi) and Kouichı Kita (Advanced Medical Equipment Department, Nasu Works Toshıba, Tochıg1)
山岸義 雄 ${ }^{\dagger}$, 喜多紘 - ${ }^{\dagger \dagger}$

医師を常時駐在させなくとも，画像伝送によって専門 医の診断が受けられる体制が作られていたこれは 1970 年頃の例であり, その後, 遠隔地医㞠サービス, 軍での利用など応用が広がり, 伝送用機器の開発が続 いているが, 基本的には ITV とビデオディスプレイ 技術の応用になっている

テレビ信号伝送がアナログ信号からディジタル通信 網利用になり, 応用が広がってきた現在, 先進の米国 では, イメージングセンタ(高度医用機器の画像検 查・診断の集中サービスセンタ) と利用病院との通信 や，衛星通信を利用した退院患者の画像を含む診㞠録 情報の集中保管・検索サービスなどへの展開が事業化 されつつあるこれらの Teleradiography の応用は, 既存の技術やサービス網を利用することが多く，技術 開発の面で特に医用として強調する技術は少ない

この Teleradiographyの実用化に比べ, PACSは 完成されたシステムがまだ導入されたところはないな ど, 実用システム開発・導入は何年か先と考えられて いる PACSの基盤になる要素技術の課題レベルが まだ高いこと, 導入価格も膨大になること, 病院内の 体制の隼備が必要になることなどの要因が数えられる が, やはり技術課題の解決が最大テーマであろうし たがって, 現在の PACS 計画は, 部分的な実験シス テム開発・評価・限定した診断利用システムが中心で あり, 一方でトータルシステム化で必須になる技術課 題解明の要素技術開発が続けられている

ここでは,このPACSのための要素技術として開 発されている主要テーマのうち, 他分野の画像に比べ 医用画像が膨大な情報量を持つことに基因する医用画 像通信ネットワークおよび画像圧縮技術の課題につい て述べるまた，現有の技術の組合せによって実現さ れ利用されているPACSのモデルシステムの例や, ディジタル画像の Teleradiography の例として, 衛 星を利用した医用画像通信実験の例も併せて紹介す る 


\section{2. 医用画像通信ネットワーク技術の課題}

\section{1 PACS の機能}

PACS は, X 線 CT スキャナ, X 線診断装置等の 各種医用画像診断機器で発生した画像を磁気ディスク や光ディスク等の大容量ファイルに保管し, LAN (ロ ーカルエリアネットワーク)で結合された高速演算装 置や各種ワークステーションへ画像を伝送するシステ ムといえる.

\section{2 発生デー夕量}

表 1 は， 600 床の病院の 1 日の平均的な発生デー夕 量を示している.表を見てわかるように，X線画像 が発生デー夕量の $8 \sim 9$ 割を占める. X 線 CT スキ ヤナの画像 1 枚当たりのデー夕量は, ほぼファクシミ リの A 4 のデー夕量と等しくなる.一方, X 線画像 はその 10 倍である。しかし, X 線 CT スキャナ画像 は 1 検查あたりの撮影枚数が多いので， 1 検查当たり のデー夕量はほぼ X 線検査と等しくなる.

\subsection{PACS に要求されるネットワーク}

PACS の機能からみた画像データの流れは, 画像 診断機器から大容量画像ファイルおよび, 大容量画像 ファイルからワークステーションへという方向性を持 っている。

画像診断機器から画像ファイルへの画像収集の流れ は, 放射線部門内部に限られるのに対して, 画像ファ イルからワークステーションへ至る画像配送の流れ は, 放射線部門ばかりでなく, 外来, 病棟部門など 種々の部門に関連する。したがって, 前者を収集用ネ ットワーク (診断機器用ネットワーク), 後者を配送用 ネットワーク(ワークステーション用ネットワーク)と してそれぞれを別々のネットワークとするのがネット ワーク管理面やシステム設計面からみて実用的であ る.
収集用ネットワークに要求される平均伝送速度は, 発生データをすべて 4 時間で大容量ファイルに保存す ると仮定すると, 約 $230 \mathrm{kB} / \mathrm{s}$ ，すなわち $1.8 \mathrm{Mb} / \mathrm{s}$ となる。イーサネットは瞬間的な伝送速度は公称 10 $\mathrm{Mb} / \mathrm{s}$ であるが, 通信手順とそのオーバヘッドを考慮 した実行速度は $1 \mathrm{Mb} / \mathrm{s}$ になる。したがって，イーサ ネットは収集用ネットワークとして少々物足りない. 収集用ネットワークは接続される機器が少なく, か つ, 設置場所も放射線部門内と限られているので, LAN 化せず, 直接, 機器間を結合する 1 対 1 の通信 でも, 要求される性能を満足させられる場合が多い.

配送用ネットワークに要求される平均伝送速度は, 画像の読影や参照のために発生デー夕量の 10 倍が伝 送されると仮定すると，画像ファイルの出口で約 2.3 $\mathrm{MB} / \mathrm{s}$ ，すなわち約 $20 \mathrm{Mb} / \mathrm{s}$ となる. 現在, 高速ネッ トワークとして複数のイーサネットの支線系 LAN を $100 \mathrm{Mb} / \mathrm{s}$ の光リング幹線系 LAN で結合した階層構 造型ネットワークが実用化されている ${ }^{1)}$ 。このネット

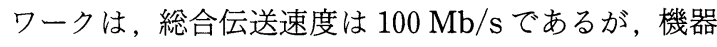
に接続されるインタフェースでの実効速度は $1 \mathrm{Mb} / \mathrm{s}$ なので, 配送用ネットワークには使用できない。配送 用ネットワークとして, 画像ファイルの出口が高速な ネットワークの開発が必要である。そのほか, ネット ワークを実用に近づけるためには, 画像ファイルを分 散させるとか, 面像ファイルの出口を複数個作るな ぞ, 負荷を分散させることにより, インターフェース に要求される伝送速度を下げることも有効である.

\section{4 インタフェースの標準化}

ネットワークが高速になっても, 機器接続のための インタフェースが標準化されないと, 各メーカの機器 が接続できず，PACSの発展を阻害する．インタフ エースが標準化されていると, ユーザは特長のある機 器を組合せ, 最適なシステムを構築することができ

表 1 発生デー夕量

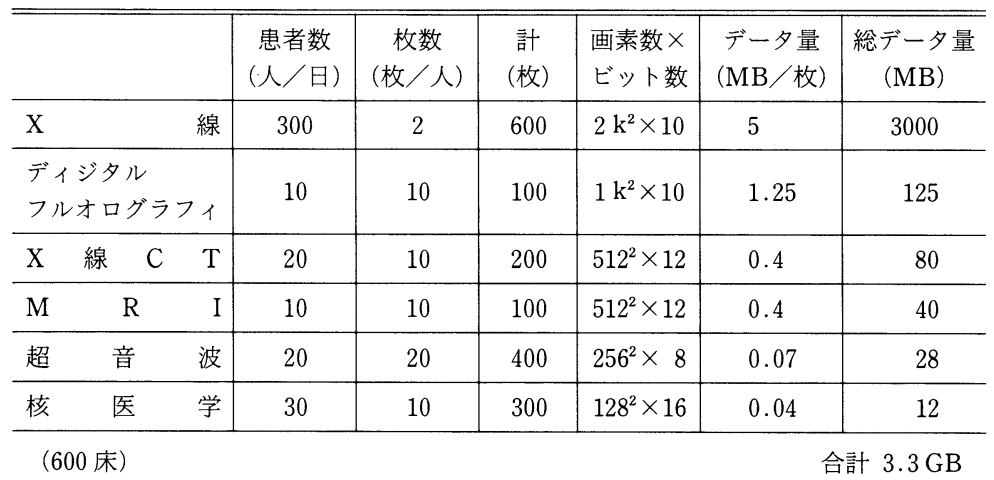


る.こうした医用ディジタル面像通信用インタフェー スの標準化を目指して,アメリカのユーザ側の団体で ある ACR とメーカ側の団体である NEMA が共同 で, ACR-NEMA 規格を提案している2).

これは, 医用画像機器間どうし, または, 医用画像 機器とネットワークインタフェースユニット (NIU) 間の画像伝送手順を決めたもので，医用 LAN の規格 ではない. LAN とはNIUを介して接続することを 仮定している. 現在, アメリカの 2,3 のメーカはイ

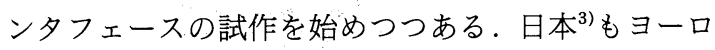
ッパもこれを意識して，PACS 用インタフェースを 規格化しつつあるので，いずれ国際的な標準規格にな ると思われる。

ACR-NEMA 規格の伝送手順は, OSI の参照モデ ルに基づいて階層化されている.コネクタは 50 ピン のマイクロタイプリセプタクルで, 双方向の 16 対の データ線, 1 対のパリティ線, 6 対の制御線, 1 対の 接地線からなる。デー夕は 16 ビットが 1 語で, 1 語 ずつパラレルに送信する．伝送手順上， 1 回に送信で きるパケットは 2048 語以下なので, 画像やその付帯 情報を送るためには, 複数のパケットに分けて送信す る。

伝送できる情報は, コマンド, 画像付帯情報, テキ スト, オーバレイ, 画素データである. 各情報は項目 に分かれ，その語長は可変である.コマンドはそのあ とに続く情報の取扱い方を指示する.コマンドの種類 には, 送信コマンド, 受信コマンド, 転送コマンド, 検索コマンドおよび対話コマンドがある.

画像付帯情報は, ID 情報, 患者情報, 収集情報, 関連情報および画像表示情報などからなる．オーバレ イはビットマップとして送る. 画素データは 2 の補数 か符号なし整数で表される. 画素数およびビット数は 画像表示情報で規定する.

ACR-NEMA 規格は，画像 1 枚 1 枚を送信するの に適しているが, シネモードのような連続した画像を 管理しにくいこと，画像ディレクトリは受信側で作成 する必要があること, エラー処理の規定が不明確であ ること, あるいはネットワークとして使いにくいこと 等の欠点もあり, 今後改良されていくものと思われ る.

\section{3. 医用画像圧縮技術の課題}

\section{1 画像圧縮の種類}

画像の質を損うことなくデー夕量を減らすことがで きれば, 画像ファイルに要求される容量と, 画像通信 に要求される伝送速度を減らすことができる。縦およ
び横方向に画素を配列した原画像は, 空間的に隣接し た画素が高い相関を持っているため, 情報量的に高い 圥長度を持っている. 画像圧縮はその圥長度を減ら し，1画像当たりの総ビット数を減らすことにより実 現される。

ディジタル画像の圧縮法には大きく分けて, 画像圧 縮されたデー夕を復元したとき, 各画素值が理論的に もとのディジタル值に戻せる可逆圧縮法と, もとに戻 せない非可逆圧縮法がある.X線画像に対して, 原 画像の性質と用途により, 前者の方法で $1 / 2 \sim 1 / 4$, 後者の方法で $1 / 10 \sim 1 / 20$ 位まで圧縮可能である.

\section{2 可逆圧縮}

可逆圧縮の代表的な方法は DPCM (差分パルス変 調)である.これはある点の画素值と, その画素の周 辺からの線形予測值との差をとり, その差をハフマン コードを用いて符号化し, 冗長度を削減する方式であ る. 線形予測は最も簡単な場合は 1 つ前の画素を用い る.すなわち，隣り合った画素の差を作る．八フマン コード化は出現頻度の高いものからビット数の短いコ ードを割り当てて変換する方式である.また, その差 が一定值を越えるとエスケープコードを先行させ，そ の後, 実際の画素值を続け, 次からまたハフマンコー ドを続ける。

画像を複元するときはハフマンコードを差の值に変 換し, 初期值にその差を順次加算し, 画素値を作る. この方式は復元された画素值が完全にもとのディジ夕 ル值に戻り, 画質劣化がないので, 臨床上は圧縮を意 識せずに使用できる。

\section{3 非可逆圧縮}

非可逆圧縮は一般に, 画像のブロック化, 直交変 換, 量子化, および符号化の順に行われる. 量子化お よび符号化の過程で非可逆な変換を行うので, その可 逆性が失われる。画像のブロック化では画像を小さな ブロック画像に分け, 各ブロック画像ごとに直交変換 を行う. 普通, $16 \times 16$ のブロック画像に分けること が多い，画像をブロック化すると, 非可逆圧縮のため 各ブロックの復元画像が原画像と異なるため, ブロッ ク画像の境界で連続性が損われ, 復元画像にブロック アーチファクトが出ることがある.これは, 画像全体 をブロック画像に分けず一度に変換することにより防 げるが，一方では圧縮時間が長くなり，また，ブロッ ク画像毎に変換数を変えてさらに圧縮率を上げること ができなくなる等の欠点もある.

直交変換には, フーリエ変換, ハール変換, アダマ ール変換, 傾斜変換, 離散型コサイン変換 $(\mathrm{DCT})$ や $\mathrm{K}-\mathrm{L}$ 変換等が提案されている. 原画像と復元画像の 
差の平均 2 乗誤差を最小にする変換方法は $\mathrm{K}-\mathrm{L}$ 変換 であるが, 高速変換のアルゴリズムを持っていない． 次に $\mathrm{K}-\mathrm{L}$ 変換に近い性能を持っている変換は離散型 コサイン変換である ${ }^{4)}$.これはFFTアルゴリズムに よって計算されるので, 高速化が可能である。したが って, 非可逆圧縮方法として DCT が広く検討されて いる.

量子化では, DCT 後の係数を正規化する正規化係 数と, 正規化後の係数が一定值以下であれば零とする 閾值を定め, DCT 後の係数を変換する. 符号化はい ろいろな方法がある. あらかじめ決められた周波数成 分のみをハフマンコードに変換する方法 (アダプティ ブマップ法), 各周波数成分毎に使用できるビット数 を決めておく方式(ゾーナルビットアロケーション法) などがある．最終的にはこのコード化されたものが圧 縮データである，復元はこの逆をたどり，逆 DCT を 行い, 復元画像を得る.

\section{4 非可逆圧縮の圧縮率評価}

非可逆圧縮は, その圧縮率が復元画像の画質に影響 を与えるので, 実用的圧縮率を決定するのが難しい. 復元画像と原画像の差画像に何の構造もみられず, ラ ンダムなノイズのみであれば画質の劣化がないといえ る。しかし, 完全なノイズ画像との判断は難しい。ま た差画像に構造がみられても, それが復元画像で見え ているものであれば情報を落としたことにならないと の考え方もある.また将来, 新しい画像処理方法が開 発されて今まで見えなかったものが見えるようになっ た場合, 非可逆圧縮された復元画像からはその情報が 出てこない可能性もある.

したがって, 参照用画像とかコンサルテーション用 画像とか目的が明解で, それ以外に使用される見込み がなく, かつ, 目的とする所見が復元されているのを 確認後, その圧縮画像を保管または伝送するように し, それ以外の場合は可逆圧縮で保管するのが現状で は無難である。

\section{PACS のモデルシステム例}

写真 1 にPACSのモデルシステムの一例として, 医用画像ファイリング装置を示す。本装置(TDISFILE) は, データ処理装置, フィルムディジタイザ, システムコンソール, 画像表示装置, 光ディスク装置 1 台が基本システムで, オプション機器には増設用画 像表示装置, 増設用光ディスク, 診断装置のオンライ ン接続用インタフェース, 光ディスクオートチェンジ ヤ, フィルムレコーダがある ${ }^{5)}$. 本装置は PACS に要 求される基本機能をもち, パイロットシステムあるい

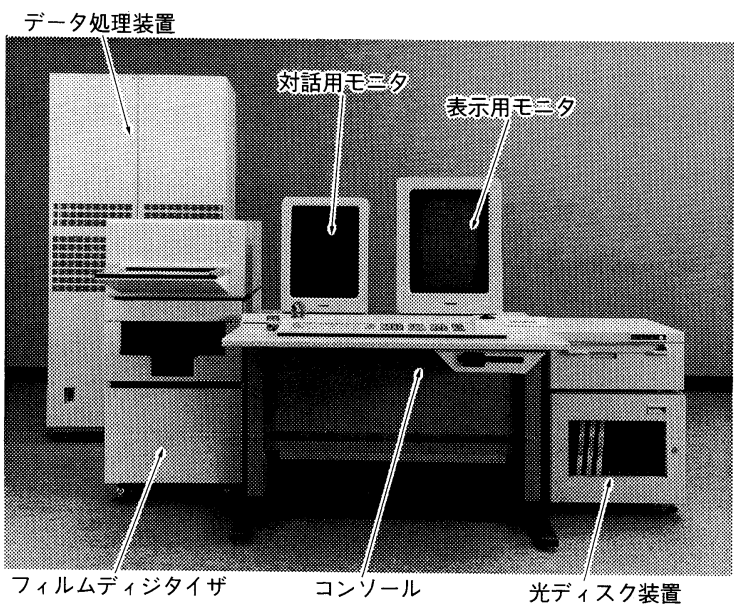

写真 1 画像ファイリング装置 (TDIS-FILE)

は中小規模 PACS の構成要素として開発された装置 である。

\section{1 デー夕処理装置}

$\mathrm{X}$ 線画像のデー夕量は膨大であるため, このデー 夕を許容できる時間内に拡大, 縮小や空間フィル夕等 の処理を行うためには, デー夕処理装置として非常に 高速なものが要求される. 本装置はそのためにメモリ 一容量 32〜128 MB の高速演算装置, $200 \mathrm{MB}$ の画像 用高速バスおよび 1 6 GB の磁気ディスクを持つ.

\section{2 画像データの収集}

本装置は CR (コンピューテッドラジオグラフィ) シ ステムとオンラインで接続し, 直接デー夕を収集する ことができる． CR システムは X 線の検出器としてイ メージングプレートを用い, イメージングプレートを $\mathrm{He}-\mathrm{Ne}$ レーザで走査しディジタル化する.

また, すでにディジタル化されているCT（コンピ ユーテッドトモグラフィ) スキャナ, MRI（磁気共鳴 イメージング）装置や核医学装置等ともオンライン接 続でき, データを収集できる.

\section{3 フィルムディジタイザ}

$\mathrm{X}$ 線フィルムの画像は, 画素数 $2000 \times 2500$, 濃度 分解能 1024 のディジタルデータとして読込まれる. $\mathrm{X}$ 線撮影装置で撮影されるX線フィルムは, その黒 化度が $0 \sim 3.0$ 以上までの広い範囲に分布している。 濃度分布の広い $\mathrm{X}$ 線フィルムをディジタル化するた

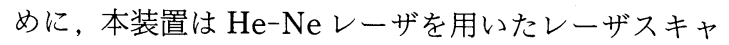
ナとフォトマルチプライヤを採用している.

\section{4 光ディスク装置}

画像デー夕の保管には 12 インチの光ディスクを使 用する. 光デスクは両面で $5.0 \mathrm{~GB}$ の記憶容量を持っ 
ている.1/2 の可逆圧縮を行うと約 1700 枚の X 線フ イルム保管できる. 光ディスクオートチェンジャは 25 枚の光デスクを収納し, 自動的に光ディスクドラ イバにかけおろしできる。したがって，1台当たりの 容量は $125 \mathrm{~GB}$ となり, 4 台で 1 年分のファイル容量 を確保できる。

\section{5 画像の表示}

画像表示装置は，表示マトリックス $1025 \times 1536$ で， スキャンライン 1635 の 20 インチ縦形モニタである. 図 1 に示すように，525 本の標準テレビ 6 台分に当た り，画像の表示およびフォーマットについては診断の 形態に応じた表示が可能である．特に縦形の $\mathrm{X}$ 線

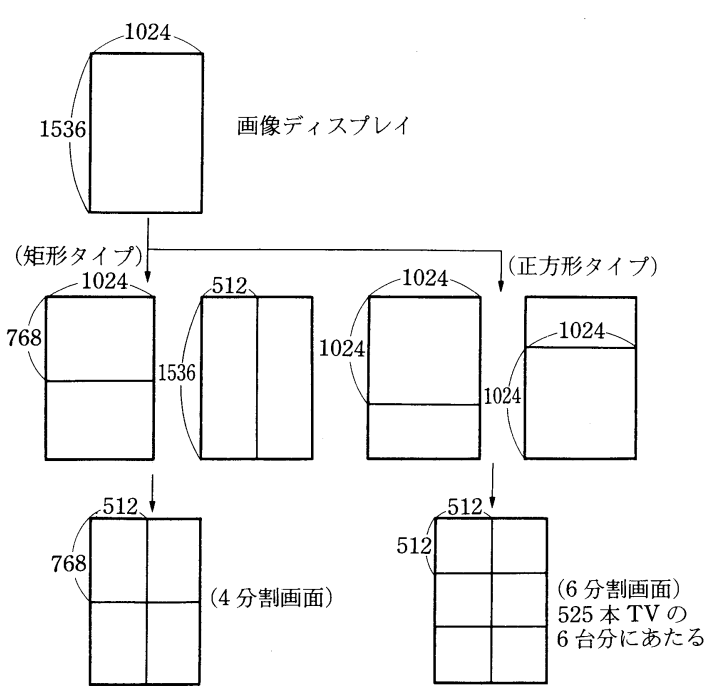

図 1 画像表示フォーマット

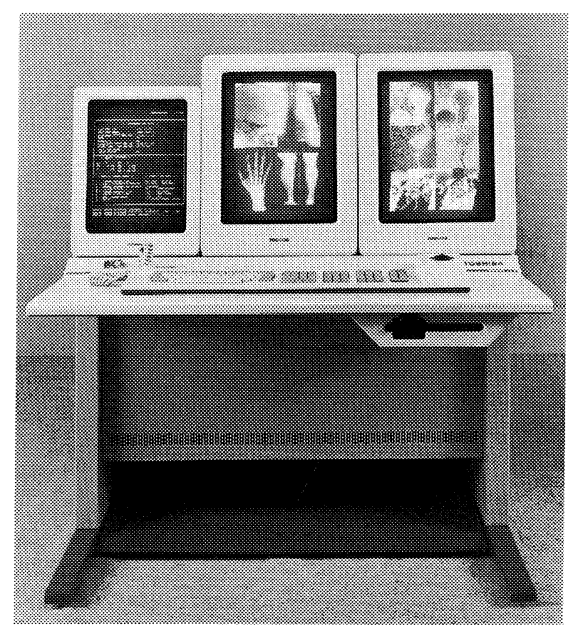

写真 2 コンソールの画像表示例
イルム等の観察に有効である．写真 2 は，2台のモニ 夕を持つコンソールの画像表示例を示す. 本装置は, 本コンソールを複数台接続し, 放射線部門以外の場所 でも画像を参照することができる．

\section{6 中小規模 PACS への応用}

TDIS-FILE を複数台組合せることにより，中小規 模 PACS を構成することができる. 画像の収集は， デー夕の発生量に合わせて複数台の TDIS-FILEに分 散させる. 外来や病棟のワークステーションは, TDIS-FILE のコンソールを必要な場所, 数に応じて 設置する.コンソールの数が多くなった場合は高速 LAN を用いるが，少ない場合は TDIS-FILE 間を 1 対 1 の通信で結合してもよい.

\section{5. 衛星通信による医用画像通信実験}

\section{1 実験の目的}

医用画像を遠隔地に送ることは，緊急時に専門医の コンサルテーションを受けたり，離れた場所にいる複 数の医師が, 症例検討会を行うのに有効である.日本 医学放射線学会, 日本放射線技術学会と日本放射線機 器工業会の三者が合同で運営する JMCP 88 学術大会 が, 市川平三郎会長(国立ガンセンタ)のもとに, 1988 年 3 月 29 日〜 4 月 3 日まで東京晴海にて開催され, その特別企画として, 九州大学病院と東京晴海会場の 間で通信衛星を介して，ディジタル医用画像を伝送 し, 症例検討会が行われた. 本企画は, 同時に開催さ れたCS-2による衛星利用パイロット計画フェアの一 環としても行われた。

症例検討会をサポートするために，ディジタル医用 画像伝送以外に，テレビ会議用のコーデックを衛星回 線を切替えて使用した。また，音声は地上回線を用い $た^{6)}$.

\section{2 システム構成}

図 2 にシステム構成を示し，以下，簡単にその役割 を述べる。

（1）TDIS-FILE：東芝製医用画像ファイリング 装置 (4.で説明した装置). 画像表示および画像 ファイルとして使用.

（2） VAX, $\mu \mathrm{VAX}: \mathrm{DEC}$ 社製コンピュータ. TDIS-FILE と HYPER channel 間のゲートウ エイとして使用.

（3） HYPER channel：住商エレクトロニクス製 高速コンピュータネットワーク装置. 衛星回線 系を含めたネットワークシステムとして使用.

（4）MODEM：東芝製モデム. 衛星回線系と HYPER channel のインタフェースとして使 


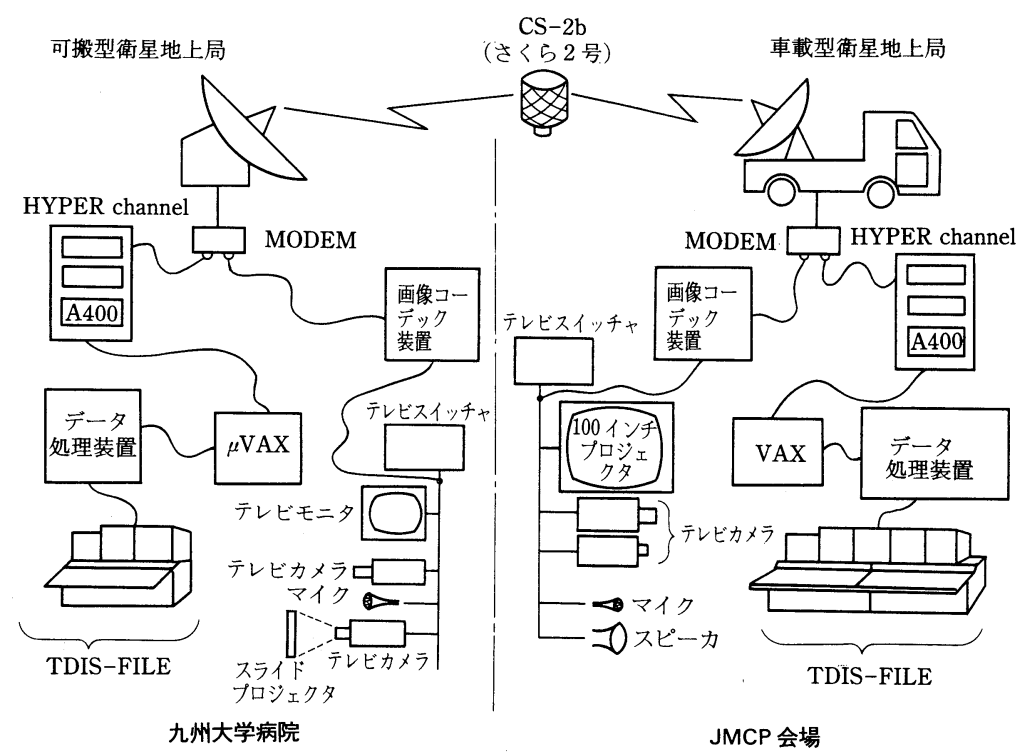

図 2 医用画像通信実験システム構成図

用.

（5）画像コーデック装置：東芝製テレビ会議用画 像高能率符号化伝送装置. テレビ会議用として 使用.

（6）車載型衛星地上局：東芝製衛星地上局. $2 \mathrm{~m}$ カセグレンアンテナと自家発電機を搭載した移 動型 2 トン車.

（7）可搬型衛星地上局: 富士通製衛星地上局. 3 $\mathrm{m}$ カセグレンアンテナを含んだ送受信装置と 端局装置, 発電機から構成されている可搬局.

（8） CS-2 b:さくら 2 号, 日本初の実用通信衛 星. $20 / 30 \mathrm{GHz}$ を使用. 伝送速度は 1.544 $\mathrm{Mb} / \mathrm{s}$.

\section{3 実験結果}

テレビ会議用の動画像伝送と医用画像用の静止画デ イジタル画像伝送を同時に評価することができた，天 候や送信電力により $S / N$ が悪くなると, テレビ会議 用伝送系では, コーデック特有のブロック状のノイズ がのり, 医用画像用伝送系では画質は変化しないが, $\mathrm{X}$ 線画像 1 枚当たりの伝送時間が $25 \sim 60$ 秒位まで変 化した.この伝送時間の延長は伝送誤り率によりパッ ケットサイズを最適值に調整することにより改善され るが, 本実験ではその最適化は行わなかった。

本実験での伝送速度のボトルネックは，ゲートウェ イとしての VAXのオーバヘッドであったＶVAXの オーバヘッドは, ソフトウェアの改良で改善可能であ るが, 今回は間に合わなかった。
医学的には，本システム構成にて $1024 \times 1536$ 画素 の 20 インチモニ夕を複数台並べることにより, 九 州・東京という離れた場所でも X 線画像や CT 画像の 症例検討会ができることがわかった。

\section{6. む す び}

医用画像ネットワーク技術として, 主に通信ネット ワークおよび画像圧縮を中心に述べてきた。これから PACS が普及するためには，CRT 診断(ソフトコピ 一診断)を可能にするためのワークステーション機能 の充実と性能の向上が重要である.また, 光ディスク へ画像デー夕を効率良く保管し，有効にそのデー夕を 活用するためには，階層化された分散型のデータベー スの開発が必要である。

そのうえ, PACSを日常のシステムとして運営し ていくためには, 病院情報システムや, 放射線部門情 報システムなどの画像以外のシステムと有機的に結合 させる必要がある。

PACS は,これから病院内のコンセンサスをとり ながら構築していくシステムなので, シーズとニーズ のバランスをとりながら一歩一歩着実に進めていくこ とが大切である。

(1989 年 3 月 17 日受付)

\section{〔参 考 文 献〕}

1）誉田, 嶋本, 古西：“ローカルエリアネットワーク TOTAL -LAN の異機種接続技術”，東芝レビュー， 43，2，pp. 103106 (Feb., 1988)

2) ACR-NEMA Standards Publication/No. 300-1985: Digi- 
tal Imaging and Communications (1985)

3）日本放射線機器工業会編：“デジタル画像と通信規格 MIPS 規格案-87” (1988)

4） R. H. Stanford: “最新デジタルテレビジョン”, pp. 100105，(株）日本技術経済センター，東京（1982）

5）東：“「86 RSNA "PACS”の動向」と「Toshiba Total Digital Imaging System」”, 映像情報 (M) , 19, 2, pp. 77 -80 (1987)

6) Azuma, Kato, et al : "Digital Imaging Transminnion via Satellite”, Medical Imaging Technology, 6, 2, pp. 153-154 (1988)

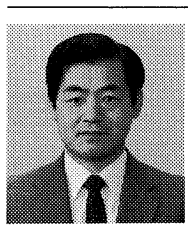

喜㝖 紘一昭和 42 年, 東京大学工学部 電子工学科卒業. 同年, (株) 東芝に入社. 医 用電子装置, 画像処理機器, PACS 機器の 開発に従事. 現在, 同社那須工場に勤務. 放 射線機器工業会等で, PACS 用インタフェ 一スの標準化を推進.

山岸義雄 昭和 37 年, 早稲田大学理工 学部電子通信学科卒業. 同年, (株) 東芝に入 社. 医用電子, CT，医学コンピュー夕応用 機器開発に従事. 現在, 同社医用機器技術研 究所所長.

\section{9 年 8 月号「立体視・3 次元表示」小特集予定目次}

【ふお一かす】 東 大 大越孝敬

【小特 集】 1. 奥行き知覚の要因とメカニズム 東京工芸大 畑田豊彦, 製科研 斉田真也

2. 3 次元表示技術アラカルト

2-1 液晶シャッ夕を用いたフィールドシーケンシャルステレオ装置

首藤恭三

2-2 多眼式 3 次元映像表示 東 大 浜崎襄二

2-3 ホログラフィ式 3 次元表示 京都工繊大 久保田敏弘

3. 3 次元表示応用アラカルト

3-1 3 次元テレビジョン ……………………….................................. H K 元木紀雄

3-2 3 次元画像通信 …………………………………… T T 安田 浩・一ノ瀬進・渡辺 裕

【技 術 解 説】ファクシミリ放送方式の概要 郵政省 河内正孝

【技術の話題一放送番組技術賞受賞記事一】

「芸術劇場」の番組制作一字幕スーパーシステムの開発—………………………… H K K 右近行洋

「チョモランマがそこにある」の番組制作のために開発した各種機器とエピソード 日本テレビ 田中元一

「第 23 回福岡国際マラソン」の番組制作一タッチパネルを使ったスーパー装置—

【講

座】 画像情報圧縮の手ほどき（第 3 回）：画像情報圧縮のための画像信号論

$\cdot \mathrm{NH} \mathrm{K}$ 福岡 愛甲明毅・新城 彰

【論

文】画像の変換符号化において再現誤差に対して伝送レートを最小にするビット配分

原田治行・太田諦二

VTRの再生回路系におけるへッド/テープ系ノイズの理論的解析………松下電器 黒江章郎・杉田龍二 パーソナルコンピュータを用いた文庫本小説の印刷漢字認識実験………岡山理科大 島田恭宏・塩野 充 多チャンネル P C M音声衛星放送伝送方式……………………… H K 河合直樹・亀田耕造・吉野武彦

【これすぼんでんす】 3 板カメラ撮像ブロックの密着一体化実装

松下電器 熱田裕史 ・ 片野光詞 ・ 富田孝明 - 内田真司 ・ 米澤武敏

【研 究 速 報】

【会議レポート】

NCTA

ケーブルテレビジョン東京 斉藤庸之助

SID 松下電器 橋口淳平

ICASSP NTT 渡辺 裕

ICC NTT 大西広一

ICCE 東 芝 竹内久晴

ISCAS

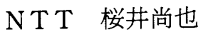

